Diabetologia 7, $349-356$ (1971)

(C) by Springer-Verlag 1971

\title{
Metabolism and Oxidation of U-14C-Glucose, Xylitol, Fructose and Sorbitol in the Fasted and in the Streptozotocin-Diabetic Rat*
}

\author{
U. KeLLER** and E. R. FroescH \\ Metabolic Unit, Department of Medicine, University of Zurich, Switzerland
}

Received: June 15, 1971, accepted: July 26, 1971

Summary. 1. 24-h-fasted rats exhaled $35-37 \%$ of i.v. administered loads of labelled glucose, xylitol and fructose, and $20 \%$ of a sorbitol load as ${ }^{14} \mathrm{CO}_{2}$ within a period of six hours. 2. Streptozotocin-diabetic rats exhaled under similar conditions only $11-18 \%$ of these substrates as ${ }^{14} \mathrm{CO}_{2}$. The rate of glucose oxidation was similar in both groups of animals when a correction for the different glucose pool size was applied. It is concluded that glucose oxidation to ${ }^{14} \mathrm{CO}_{2}$ takes place mainly in tissues which are not sensitive to insulin. 3. Urinary ex cretion of all substrates was $39-55 \%$ of the given dose in diabetic rats. The large difference of urinary carbon-14 between fasted and diabetic rats was due to the excretion of glucose- ${ }^{11} \mathrm{C}$ by the diabetic rats. 4 . Six hours after the administration of all four substrates, similar amounts of carbon-14 were recovered in serum, serum osazones, liver glycogen and total lipids and diaphragm glycogen within each group of animals. It is concluded that the similarities of the metabolism of all substrates is due to the rapid conversion of the substitute sugars to glucose.

Métabolisme et oxydation du glucose, du xylitol, du fructose et du sorbitol, uniformément marqués au ${ }^{14} C$, chez le rat à jeun et le rat rendu diabétique par la streptozotocine

Résumé. 1. Chez des tats à jeun pendant $24 \mathrm{~h}, 35-37 \%$ d'une forte quantité de glucose, de xylitol ou de fructose marqués injectée par voie intraveineuse, et $20 \%$ de sorbitol sont exhalés en six $h$ sous forme de ${ }^{14} \mathrm{CO}_{2}$. 2 . Des rats diabétiques par la streptozotocine exhalaient en $6 \mathrm{~h} 11$ $18 \%$ de ces substrats sous forme de ${ }^{14} \mathrm{CO}_{2}$. Après correction pour les pools différents de glucose, l'oxydation du glucose est semblable chez les deux groupes d'animaux. Lioxydation du glucose en ${ }^{14} \mathrm{CO}_{2}$ semble done avoir lieu surtout dans des tissus qui ne sont pas sensibles à l'insuline. $3.39-55 \%$ de la dose de chaque substrat étaient excrétés dans l'urine pendant six heures par les rats diabétiques. La différence considérable de l'excrétion urinaire du ${ }^{14} \mathrm{C}$ entre les rats à jeun et les rats diabétiques est due à l'excrétion de ${ }^{14} \mathrm{C}$ sous forme de glucose chez les rats diabétiques. 4 . Six heures après l'injection des 4 substrats, des quantités semblables de ${ }^{14} \mathrm{C}$ étaient retrouvées dans le sérum, les osazones du sérum, le glycogène et les lipides totaux du foie, et le glycogène du diaphragme dans chaque groupe de rats. Les similitudes du métabolisme des 4 substrats sont probablement dues à la conversion très rapide du xylitol, du sorbitol et du fructose en glucose.

Stoffwechsel und Oxydierung von $U^{-11} C$-Glucose, $X y l i t$, Fructose und Sorbit bei fastenden und Streptozotocin-diabetischen Ratten

Zusammenfassung. 1. 24 Std lang fastende Ratten exhalierten in $6 \mathrm{Std} 35-37 \%$ einer intravenös verabreichten Menge markierter Glucose, Xylit und Fructose und $20 \%$ von Sorbit als ${ }^{14} \mathrm{CO}_{2}$. 2. Streptozotocin-diabetische Ratten exhalierten von derselben Subtratmenge unter gleichen Bedingungen $11-18 \%$ als ${ }^{14} \mathrm{CO}_{2}$. Nach Korrektur für die verschiedene Glucose-Poolgröße oxydieren fastende und diabetische Ratten ähnliche Anteile der Zucker zu ${ }^{14} \mathrm{CO}_{2}$. Die $\mathrm{CO}_{2}$-Produktion aus Glucose scheint deshalb vor allem in Geweben, die nicht insulinempfind. lich sind, stattzufinden. 3. Bei diabetischen Ratten betrug der Verlust im Urin nach allen Substraten $39-55 \%$ der gegebenen Dosis. Dieser Unterschied zwischen fastenden und diabetischen Ratten ist auf den zusätzlichen Verlust großer Mengen von ${ }^{14} \mathrm{C}$ Glucose im Urin zurückzuführen. 4. Sechs Stunden nach Injektion aller vier Substrate wurden ungefähr gleiche Mengen ${ }^{14} \mathrm{C}$ im Serum, in den SerumOsazonen, in Leberglykogen und -totallipiden und im Glykogen des Diaphragma innerhalb beider Tiergruppen gefunden. Der Stoffwechsel aller vier untersuchter Sub. strate ist offenbar deshalb ähnlich, weil die Ersatzzucker sehr rasch in Glucose umgewandelt werden.

Key-words: Carbohydrate metabolism, glucose, fructose, xylitol, sorbitol, glucose $-{ }^{14} \mathrm{C}$ oxidation, gluconeogenesis, streptozotocin diabetes, insulin, parenteral nutrition.

\section{Introduction}

The recent interest in xylitol as a particularly well tolerated carbohydrate in parenteral therapy [1] and as a sweet substitute for sucrose in food $[2,3]$ revived the interest in the old debate over the problem whether or not xylitol, fructose or sorbitol have real metabolic advantages over glucose which justify their use.

* Supported by grants from the U.S. Public Health Service (AM 05387) and the Schweizerische Nationalfonds (3.85.69).

** Trainee of the third postgraduate course for experimental medicine, faculty of Medicine of Zurich.
We have compared the utilization of U. ${ }^{14} \mathrm{C}$-labelled glucose, xylitol, fructose and sorbitol by monitoring ${ }^{14} \mathrm{CO}_{2}$ in the expired air after identical loads to fasted and diabetic rats.

Fructose [4, 5], sorbitol $[6,7]$ and xylitol $[2,8]$ are metabolized in an insulin-independent way. It was of particular interest, therefore, to investigate their utilization and oxidation in these two groups of rats.

The present work indicates that oxidation of each one of these substrates is similar in both groups of rats. Their incorporation into insulin-sensitive tissues, however, is largely dependent upon the availability of insulin. 
The substitute sugars and glucose showed similar exhalation patterns and tissue distribution in all animals suggesting that they share a common fate after rapid conversion to glucose.

\section{Material and Methods}

Continuous ${ }^{14} \mathrm{CO}_{2}$-exhalation was registered with a FHT 50 A analytical respirometer manufactured by Frieseke and Hoepfer GmbH, Erlangen. This apparatus provides simultaneous registration of radioactivity (with $17 \%$ efficiency), $\mathrm{CO}_{2}$ content by infra-red absorption and specific activity of $\mathrm{CO}_{2}$.

An integrator system allows easy calculation of the total expired ${ }^{14} \mathrm{CO}_{2}$ and total $\mathrm{CO}_{2}$.

Male, pure-bred Osborne-Mendel rats on a regular diet (Nafag pellets), weighing $90-135 \mathrm{~g}$ were used.

The experiments were carried out with two rats sitting in a $5 \mathrm{l}$ all-glass cage. It was kept in a waterbath to maintain an inside temperature of $22^{\circ} \mathrm{C}$.

The rats were given $2 \mathrm{mg}$ of diazepam s.c. as a sedative before the rapid intravenous injection of $1 \mathrm{ml}$ of the examined sugar solution. $1 \mathrm{ml}$ contained $20 \mathrm{mg}$ of either substrate dissolved in Krebs Ringer bicarbonate buffer with $200 \mathrm{mg}$ of albumin per $100 \mathrm{ml}$.

The U. ${ }^{14} \mathrm{C}$-labelled substrates $(2 \mu \mathrm{Ci}$ per $\mathrm{ml}$ and per rat) were purchased from the Radiochemical Centre, Amersham, England.

Since the nutritional state influences the exhalation pattern considerably [9], the rats were used after a $24 \mathrm{~h}$ fast, at which time the best reproducible results were obtained.

Since some of the compounds given may stimulate insulin secretion, $18 \mathrm{mU}$ of crystalline pork insulin (supplied by Dr. Schlichtkrull, Novo) was added to the injected solution.

Experimantal diabetes was induced by the i. $\nabla$. . administration of $100 \mathrm{mg}$ streptozotocin per $\mathrm{kg}$ body wt. (gift from Dr. W.E. Dulin, Upjohn Company, Kalamazoo, Michigan). This N-nitroso derivative of glucosamine has the advantage over alloxan of being less toxic and, nevertheless, yielding an even better reproducible experimental diabetes $[10]$. Four days afterwards the animals were used for the experiments.

Each exhalation pattern was repeated $2-3$ times. After six hours of registration, the rats were decapitated and neck blood was collected on ice. Liver and diaphragm were rapidly excised and immediately frozen.

Serum glucose was measured with glucose oxidase (Boehringer). The specifie activity of serum glucose was obtained by the formation of osazones.

The frozen diaphragm and a portion of the liver were digested in boiling $30 \% \mathrm{KOH}$. Glycogen was precipitated with cold ethanol and twice reprecipitated before counting. Carrier glycogen was used as a precipitating aid for diaphragm glycogen.
Total lipids were extracted from the remainder of the liver with chloroform-methanol, $2: 1$ [11], the extract was taken do dryness and washed with iso-octane: glacial acetic acid, 1:1. The fatty acids were obtained by hydrolysis of the total lipids in alcoholic $\mathrm{KOH}$, and incorporation of carbon-14 into glyceride glycerol was calculated as the difference between the counts in the total lipids and those in the hydrolyzed fatty acids.

Urine was collected in parallel experiments for aix hours. Carbon-14 was counted in dried urine and after osazone formation.

Glucose and fructose in urine were determined by the hexokinase method with and without phosphoglucose isomerase (Boehringer). All radioactive samples were counted in a Picker Magnachanger, low background, flow counter and a correction was applied for self-absorption.

\section{Results}

The exhalation patterns of fasted rats are summarized in Fig. 1. Each diagram shows the registration of ${ }^{14} \mathrm{CO}_{2}$ and the percentage of the total administered dose in the expired air. $20 \mathrm{mg}$ of labelled glucose, xylitol, fructose and sorbitol together with $18 \mathrm{mU}$ of insulin were rapidly injected into the tail vein. ${ }^{14} \mathrm{CO}_{2^{-}}$ activity reaches a peak after $30 \mathrm{~min}$ with glucose, xylitol and sorbitol and after $20 \mathrm{~min}$ with fructose.

The height of the peak and the total amount exhaled as ${ }^{14} \mathrm{CO}_{2}$ after six hours was similar for glucose, xylitol and fructose (approximately $35 \%$ of the given dose), whereas less sorbitol appeared as ${ }^{14} \mathrm{CO}_{2}$ (approximately $20 \%$ ). Fig. 2 shows similar studies in the streptozotocin-diabetic rat. Compared with fasted rats, ${ }^{14} \mathrm{CO}_{2}$-production was markedly decreased, and the cumulative dose of expired ${ }^{14} \mathrm{CO}_{2}$ was $11-18 \%$ of the administered dose. The peak of maximal ${ }^{14} \mathrm{CO}_{2}$-exhalation was delayed. Oxidation of fructose was faster and gave the highest peak of all substrates.

The total amount exhaled was similar with the nonglucose substrates as with glucose. They were not oxidized in preference to glucose even in diabetic animals. The determination of serum glucose (Fig. 3) after the period of registration revealed 3-4 times higher values in diabetic as in fasted rats. No significant difference of serum glucose was observed in fasted and diabetic animals after any one of the sugars.

Six hours after injection of the label only $3 \%$ of the total amount was recovered in the extracellular space. This figure was calculated assuming that carbon-14 in serum is representative for carbon-14 in the total extracellular space and that the latter accounts for $20 \%$ of the body weight.

In fasted rats, $1 / 4$ of the counts in the serum were found in the osazones after all substrates, suggesting similar amounts circulating as glucose- ${ }^{14} \mathrm{C}$.

Streptozotocin-diabetic rats had similar carbon-14 activities in serum, but relatively more counts were 
Vol.7, No.5, 1971 U. Keller and E.R. Froesch: Glucose, Fructose, Xylitol and Sorbitol Metabolism

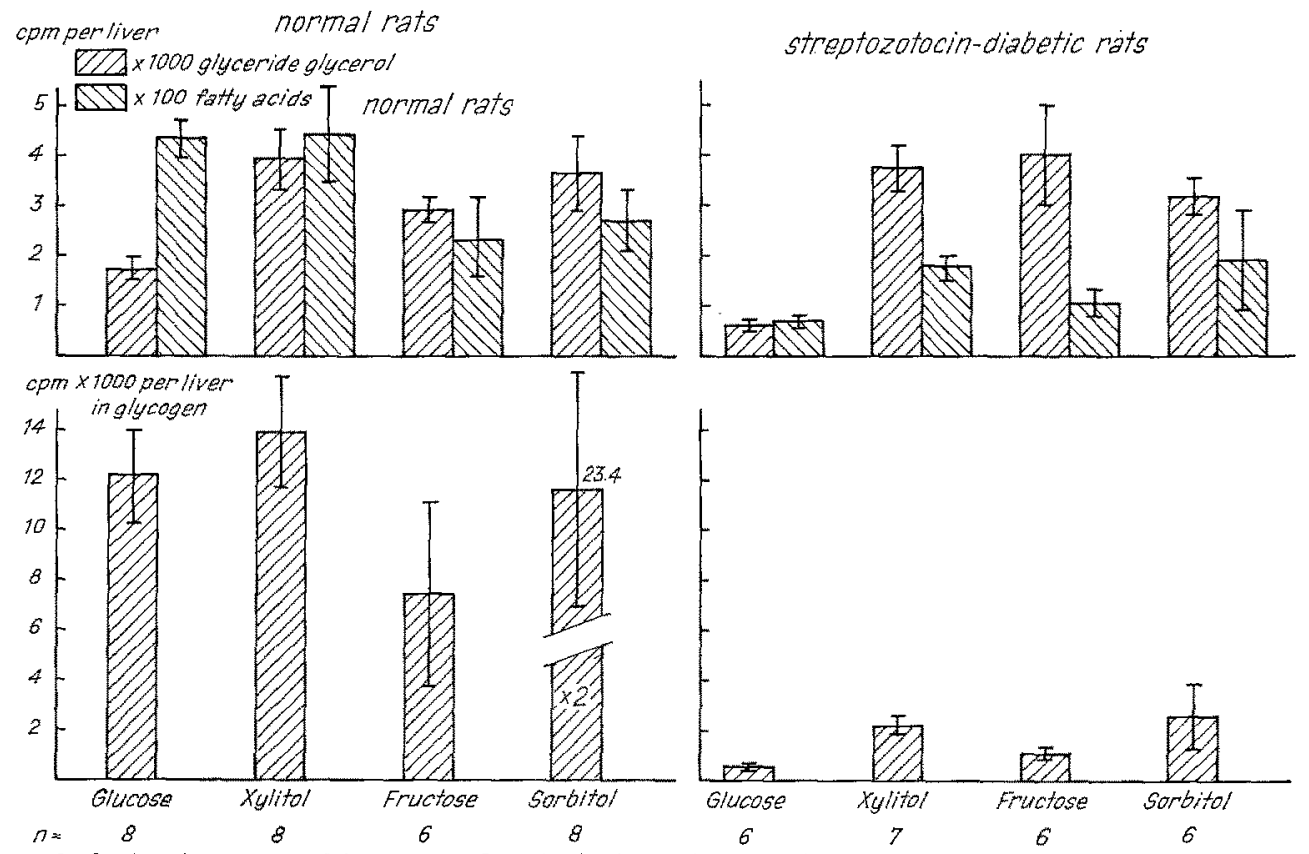

Fig. 1. ${ }^{14} \mathrm{CO}_{2}$-exhalation in epm and in accumulated \% of administered dose after U.14 C-labelled glucose, xylitol, fructose and sorbitol administration. $20 \mathrm{mg}$ and $2 \mu \mathrm{Ci}$ of each substrate together with $18 \mathrm{mU}$ of insulin were intravenously administered to two 24 -h-fasted rats. $\mathrm{N}=3$ or 4 ; brackets indicate the range

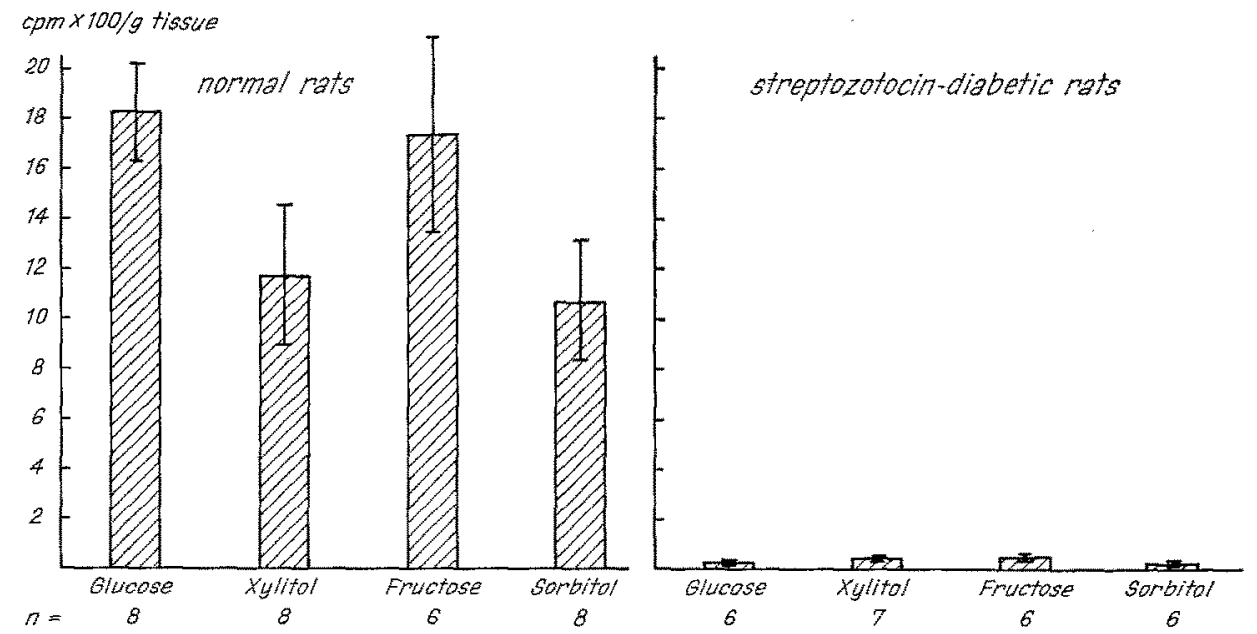

Fig. 2. ${ }^{14} \mathrm{CO}_{2}$-exhalation as $\mathrm{cpm}$ and total aceumulated dose after U-14C-labelled glucose, sorbitol, xylitol and fructose administration. $20 \mathrm{mg}$ and $2 \mu \mathrm{Ci}$ of each substrate were intravenously administered to two streptozotocin-diabetic rats. $\mathrm{N}=3$ or 4 ; brackets indicate the range
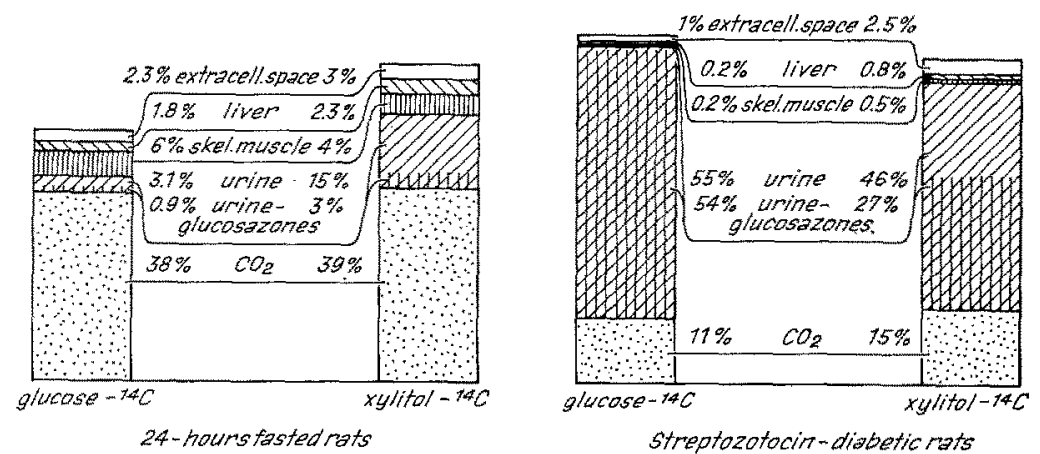

streptozotocin-diabetic rats

Fig. 3. Serum glucose, cpm per $1 \mathrm{ml}$ serum in total serum and in glucosazones six hours after i.v. administration of $20 \mathrm{mg}$ and $2, \mathrm{Ci}$ of $\mathrm{U}^{14} \mathrm{C}$-glucose, xylitol, fructose and sorbitol in the fasted and in the streptozotocin-diabetic rat. The brackets indicate the SEM 
present in serum glucose $(60-80 \%)$. More carbon-14 was recovered in the osazones after xylitol and fructose than after glucose or sorbitol. Fig. 4 shows the distribution of carbon-14 in liver. The columns in the top line represent the counts in glyceride glycerol and fatty acids.

These fractions account for approximately $0.5 \%$ of the administered dose.

The incorporation of xylitol, fructose and sorbitol into total lipids of liver was of the same order of magnitude in fasted and in diabetic rats, and in each instance exceeded glucose incorporation. Less carbon-14 of glucose was incorporated into total lipids of diabetic than into those of fasted rats.
The recovery of carbon-14 of all substrates in liver glycogen was markedly decreased in diabetic rats, particularly so with glucose.

The most striking difference between fasted and diabetic rats was observed in the carbon-14 content in diaphragm glycogen (Fig. 5).

One gram of diaphragm muscle of fasted rats contained $0.23 \%$ of the given dose, diaphragm of diabetic animals almost none. Because ${ }^{14} \mathrm{CO}_{2}$-exhalation and carbon-14 recovery in tissues did by no means add up to anywhere near $100 \%$ of the administered dose, the excretion of carbon-14 in urine was determined in separate experiments.

Table 1 shows the recovery of carbon-14 in the urine
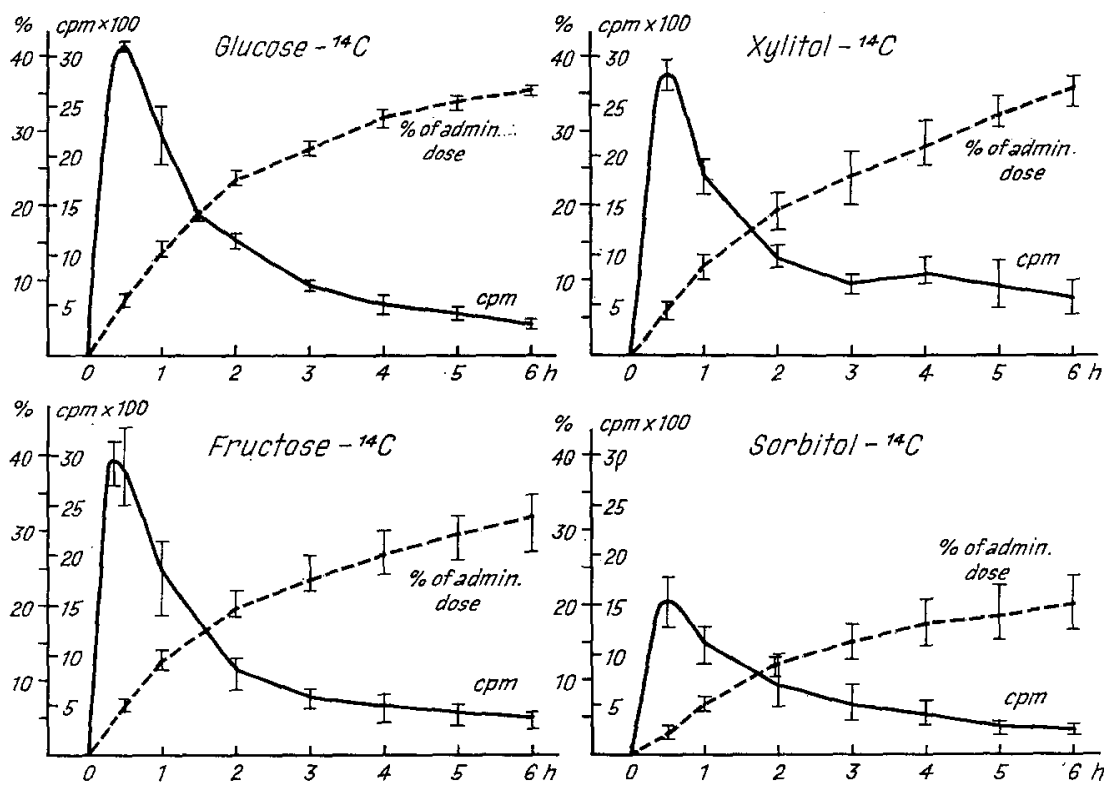

Fig. 4. Carbon-14 recovered in liver glyceride glycerol, fatty acids and glycogen six hours after i.v. administration of $20 \mathrm{mg}$ and $2 \mu \mathrm{Ci}$ of $\mathrm{U}^{-14} \mathrm{C}$-labelled glucose, xylitol, fructose and sorbitol in the fasted and in the streptozotocin diabetic rat. The brackets indicate the SEM

In each instance, incorporation into hepatic fatty acids from all substrates was decreased in the diabetic animals. This difference was most pronounced in the case of glucose.

Only $10 \%$ of carbon-14 in total lipids was recovered in fatty acids, the major portion in glyceride glycerol. Incorporation of carbon-14 into glyceride glycerol as an index of reësterification was similar for fructose, sorbitol and xylitol in both groups of rats and exceeded that of glucose.

Carbon-14 recovered in liver glycogen is plotted on the bottom line of Fig. 4.

Fasted rats showed similar conversion to liver glycogen after administration of glucose, xylitol and fructose (approximately $\mathbf{1 . 5} \%$ of the administered dose). Twice as much sorbitol was deposited as liver glycogen.
Table 1. Carbon-14 excretion in urine during six hours after $i . v$. administration of $20 \mathrm{mg}$ and $2 \mu \mathrm{C} i$ of each substrate per rat $(n=3)$. The figures represent the recovery of carbon-14 in $\%$ of the administered dose in dried urine, those in parantheses in urinary osazones from glucose and fructose, respectively

\begin{tabular}{|c|c|c|}
\hline & fasted & diabetic rats \\
\hline gluc & $3.1(0.9$ gluco & $55.4(53$. \\
\hline xylit & $15.0(3.1 \mathrm{glu}$ & 46.3 (26.6 glucose) \\
\hline fructose & $7.0 \begin{array}{cl}0.1 & \text { glucose }) \\
(5.5 & \text { fructose })\end{array}$ & $\begin{array}{r}39.4 \text { (25.0 glucose) } \\
\text { ( } 8.8 \text { fructose) }\end{array}$ \\
\hline sorbito & $\begin{array}{c}24.5(0.20 \text { glucose }) \\
(0.08 \text { fructose })\end{array}$ & $\begin{array}{c}46.3 \text { (23.4 glucose) } \\
\text { ( } 0.6 \text { fructose) }\end{array}$ \\
\hline
\end{tabular}

collected during six hours and the percentage of the administered dose in the osazones. The figures in parentheses represent the counts in urine glucose and fructose, respectively. Carbon-14 in glucose was cal- 
culated by deducting the counts in the enzymaticallydetermined fructose with a known specific activity.

In normal fasted rats, xylitol and sorbitol are excreted in considerable amounts as such. Since xylitol much as $23 \%$ and $27 \%$ of sorbitol and xylitol, respectively, were lost in the urine of the diabetic animals as glucose ${ }^{14} \mathrm{C}$.

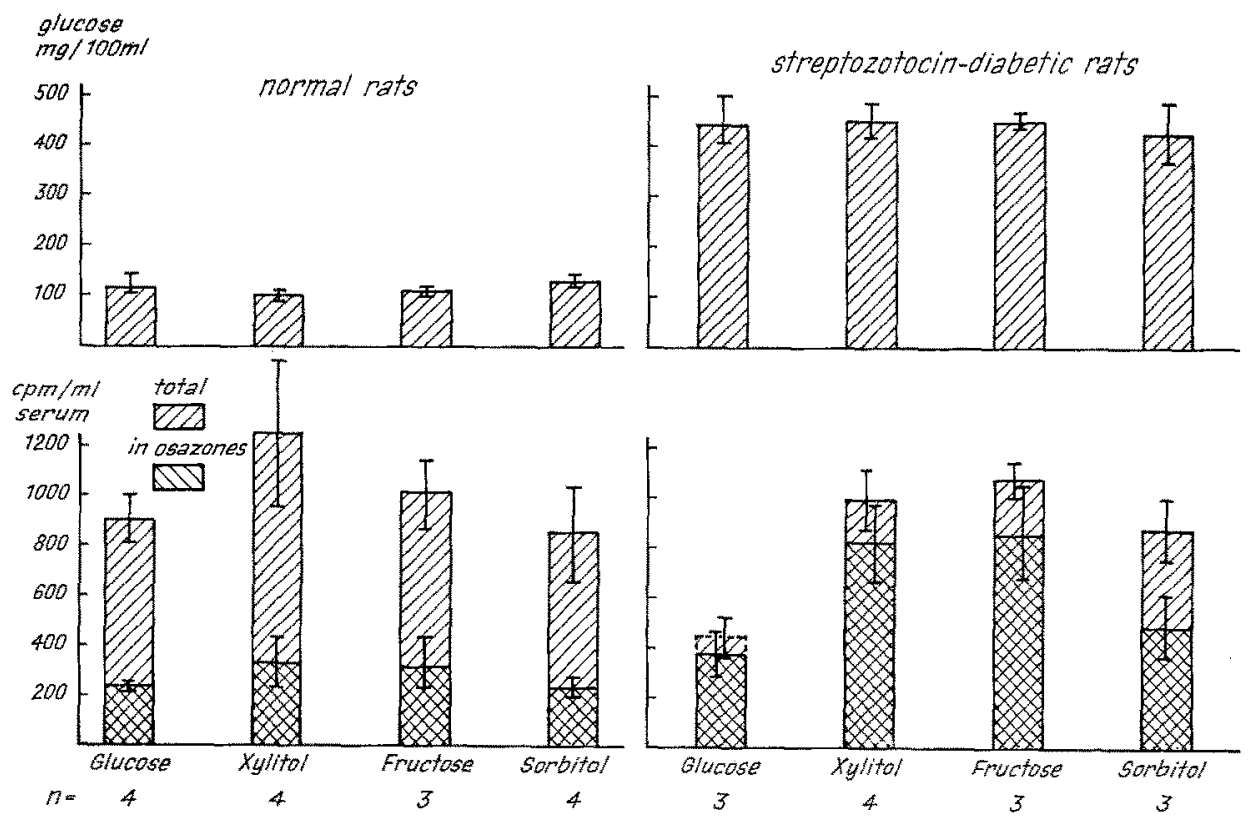

Fig. 5. Carbon-14 recovered in diaphragm glycogen six hours after i.v. administration of $20 \mathrm{mg}$ and $2 \mu \mathrm{Ci}$ of labelled glucose, xylitol, fructose and sorbitol in the $24 \mathrm{~h}$ fasted and in the streptozotocin-diabetic rat. The brackets indicate the SEM
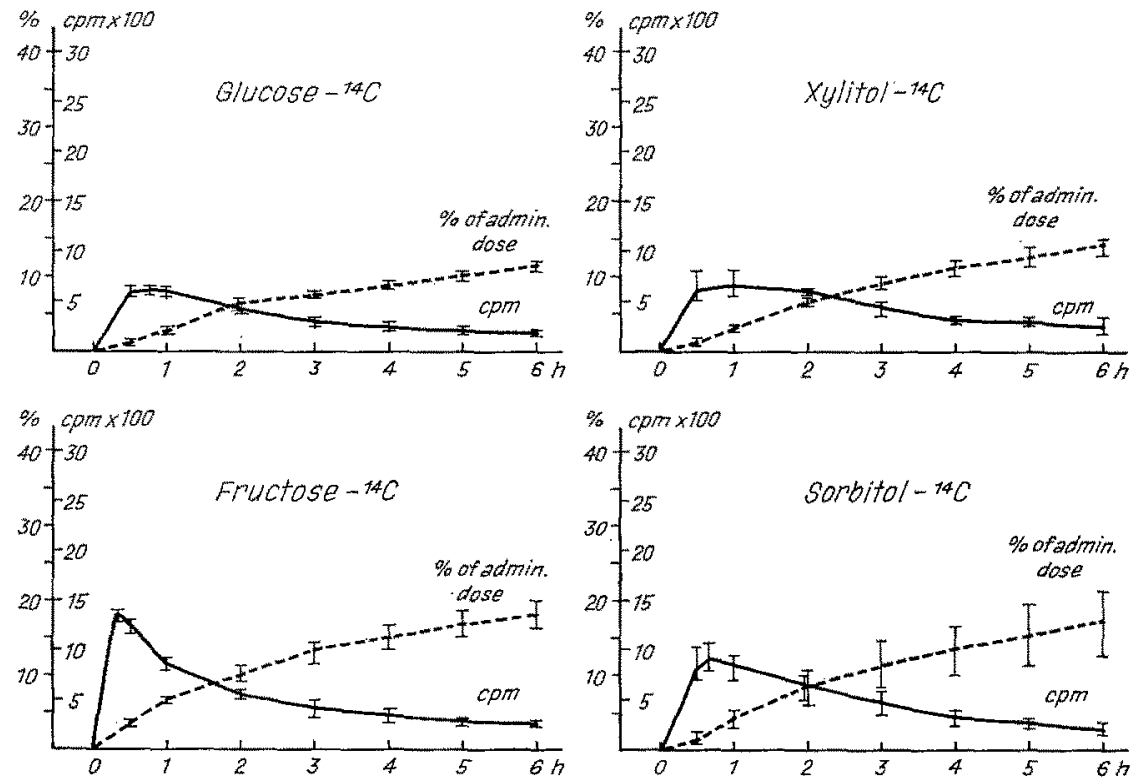

Fig. 6. Recovery of earbon-14 in ${ }^{14} \mathrm{CO}_{2}$, urine, glycogen of skeletal musele, total lipids and glycogen of liver and in the extracellular space six hours after i.v. administration of $20 \mathrm{mg}$ and $2 \mu \mathrm{Ci}$ of glucose and xylitol in 24 -h-fasted and in streptozotocin-diabetic rats

and sorbitol are probably not reabsorbed and since only little glucose was lost, the substrates must have been excreted in the urine in the initial phase shortly after their administration. It is remarkable that as

\section{Discussion}

Xylitol, fructose and sorbitol are carbohydrates which differ with respect to their initial metabolic steps. 
Xylitol has been found by Touster [12] in 1960 to be a normal metabolite of the glucuronate-xylulose path. way. A small portion of glucose is metabolized via this pathway in adipose tissue [13].

The physiologic significance of this pathway is not known. Pentosuric subjects have a decreased activity of this cycle. Since pentosuria is a benign condition, the pathway seems to be of minor importance in man [14].

Xylitol is metabolized mainly in the liver to dxylulose by a relatively unspecific cytoplasmic polyoldehydrogenase [15]. The same enzyme oxidizes sorbitol to fructose. It is a very active hepatic enzyme $(26 \mathrm{U} / \mathrm{g}$ in $\mathrm{man}, 18.9 \mathrm{U} / \mathrm{g}$ in the rat) [16]. The rapid half-life of xylitol $[17,18]$ and the failure to increase blood glucose $[2,19,20]$ lent support to the hypothesis that xylitol might be a perfect substitute for glucose in situations where glucose utilization is impaired [21, 22].

Xylitol is a potent stimulator of insulin secretion in dogs $[23,24]$. Its effect on the human B-cell is not clearly assessed, since IRI response is not uniform [22, 25]. Xylitol seems to be relatively non-toxic [3, 27], although complications after its clinical use have been reported [27]. Xylitol is poorly absorbed by the gut [21] and leads to diarrhoea when administered in large doses [2].

Fructose has been known for years to be removed from the blood independently of insulin $[4,28]$. It is rapidly phosphorylated in the liver to fructose-1-phosphate $[29,30]$. In contrast to xylitol and sorbitol, fructose enters the fat cell by a special transport system and is rapidly phosphorylated by hexokinase [31, 32]. As a precursor of $\alpha$-glycerophosphate in adipose tissue and liver, it has a marked free fatty acid lowering and antiketogenic effect [4, 31].

Fructose absorption from the gut has been estimated to be $43 \%$ that of glucose [33]. However, fructose absorption may actually exceed glucose absorption at very high concentrations [34]. Part of it is converted to glucose in the small intestine [35]. The main portion, however, is considered to be absorbed as fructose $[36,37]$.

Since detection of the sorbitol pathway in the male accessory sexual glands by Hers [38], these tissues were believed for years to be the only natural source of this polyol in man. Recent studies indicate its formation in nervous tissue $[39,40]$, in blood vessels [41] and in the lens [42], particularly during hyperglyeaemia. It may well play a pathophysiologic role in the development of diabetie neuropathy, angiopathy and cataract. I.V. administered sorbitol is rapidly converted to fructose in the liver by the action of NAD-linked polyol-dehydrogenase $[15,43]$. The latter is so effective that sorbitol metabolism is believed to proceed as rapidly as fructose metabolism. This assumption must be questioned on the basis of the results of our experiments presented in Fig. 1 and 2.

The utilization of glucose was compared with that of xylitol, fructose and sorbitol, all said to be utilized. in an insulin-independent manner.

The exhalation of ${ }^{14} \mathrm{CO}_{2}$ and the tissue distribution of carbon-14 was examined in fasted and diabetic rats for six hours. Analysis of ${ }^{14} \mathrm{CO}_{2}$-exhalation patterns with and without insulin in fasted and diabetic rats, respectively, was thought to reveal the role of glucose as a source of energy in insulin-sensitive versus insulininsensitive tissues.

Fasted rats exhaled ${ }^{14} \mathrm{CO}_{2}$ at similar rates after glucose, xylitol and fructose injection. Less sorbitol was oxidized, a finding partially explained by the considerably greater amount lost in the urine $(24 \%$ of the administered dose). The total amount of carbon-14 of all four sugars recovered as ${ }^{14} \mathrm{CO}_{2}$ and in the urine was of the same order of magnitude, and similar quantities were found in the tissues after six hours $(48-58 \%$ of the given dose).

The similar recovery of earbon-14 in the diaphragm glycogen indicated similar incorporation of all substrates after conversion to glucose. The distribution in the liver showed some differences. Sorbitol, for example, exceeded the other sugars in the incorporation into liver glycogen. Here, differences are to be expected because their incorporation into liver glycogen does not require prior conversion to glucose.

The influence of chronic experimental diabetes upon exhalation and utilization of fructose, sorbitol and xylitol shows that the absence of insulin does not change the rate of incorporation of any one substrate in a particular manner. The decreased recovery of carbon-14 in liver glycogen of diabetic animals can be explained by the fact that prolonged insulin deficiency leads to increased glycogenolysis and to decreased activity of glycogen synthetase [44]. The incorporation of carbon-14 into total lipids of liver was of the same order of magnitude in both groups of animals. Diabetic rats showed decreased hepatic fatty acid synthesis from all substrates. Carbon-14 in total lipids was mainly present in the glyceride-glycerol moiety suggesting a very active reessterification of free fatty acids from peripheral tissues being taken up by the liver. The low recovery of carbon-14 in liver total lipids after glucose administration compared with the polyols and fructose, suggests that the first step of glucose metabolism, i.e. its phosphorylation by glucokinase, is rate limiting in the diabetic rat liver [45].

The minimal incorporation into diaphragm glycogen in diabetic animals suggests that insulin is required for their storage after conversion to glucose.

Fructose was more rapidly oxidized than all other substrates. ${ }^{14} \mathrm{CO}_{2}$-production in diabetic animals increased rapidly and reached a higher peak with fructose than with the other substrates. This may be the result of insulin-independent utilization of fructose by adipose tissue $[31,46]$.

The carbon-14 activity of serum was similar in both groups of animals, but more carbon-14 was present in serum glucose of diabetic animals. 
In Fig. 6 the distribution of label in both groups of animals after administration of glucose and xylitol is compared. Incorporation into skeletal muscle was calculated under the premises that the diaphragm is representative for skeletal muscle and that the muscle mass is $20 \%$ of the total body weight.

The most striking difference between fasted and diabetic rats is the high urinary losses in diabetic animals and their decreased rate of oxidation to ${ }^{14} \mathrm{CO}_{2}$. The glucose pool in fasted rats is of the order of magnitude of $20 \mathrm{mg}$ [47] to which $20 \mathrm{mg}$ of substrate is added, whereas the glucose pool of the diabetic animals approximates to $80 \mathrm{mg}$. If the values of the ${ }^{14} \mathrm{CO}_{2}$-production of the diabetic animals are multiplied by $21 / 2$, thereby correcting for the lower specific activity of plasma glucose, the difference in the rate of ${ }^{14} \mathrm{CO}_{2}$-exhalation between the two groups of animals is minimized. The half-life of 2 to 3 min of the polyols and of fructose [37] due to their rapid conversion to glucose, explains why their rate of oxidation in the diabetic animals is the same as that of glucose. At the time when ${ }^{14} \mathrm{CO}_{2}$-production was maximal none of the originally administered substrates circulated any longer in plasma, so that most of the ${ }^{14} \mathrm{CO}_{2}$ exhaled at that time probably originated from ${ }^{14} \mathrm{C}$-glucose oxidation.

The main difference in the utilization of a carbohydrate load between fasted and diabetic rats was not found in the oxidation rate, but rather in the way it was excreted in the urine. It is well known that fructose and sorbitol are rapidly converted to glucose $[48,49$, $50]$. The conversion of xylitol to glucose appears to occur just as fast [37]. Our finding that similar amounts of carbon-14 are recovered in urinary glucosazones after the injection of all three substrates is a direct reflection thereof.

Rapid conversion of these polyols to glucose does not contradict the finding that xylitol $[2,19]$ and sorbitol [51] do not produce significant hyperglycaemia. Glucose turnover in rats is rapid and glucose homeostasis is well maintained [47]. Other gluconeogenetic substrates such as amino acids and glycerol are also rapidly converted to glucose but do not markedly elevate blood sugar.

Our data indicate that a considerable portion of the injected xylitol and sorbitol is excreted in the urine as such, within a few minutes after their administration. Diabetic animals lose a rather large additional quantity of carbon-14 as ${ }^{14} \mathrm{C}$-glucose. It has been pointed out that glucose combustion plays a minor role in total $\mathrm{CO}_{2}$-production [52]. A quantitative approach by von Holt yielded a figure of $20 \%$ in fasting rat [9].

Free fatty acids and ketone bodies appear to be the main source of energy in the rat $[53,54]$. Insulin does not influence $\mathrm{CO}_{2}$-production from glucose to a great extent [55̃].

Thus, glucose combustion to $\mathrm{CO}_{2}$ appears to take place mainly in tissues which are not sensitive to insulin, e.g. the brain. These considerations are fully supported by our findings according to which glucose combustion is only minimally decreased in diabetic rats, whereas glucose storage is deficient.

Acknowledgements: I wish to thank Mrs. A. Lang for skilled technical assistance. The ${ }^{14} \mathrm{CO}_{2}$ FHT 50 respirometer was made available through the courtesy of Hoffmann - La Roche and Co., Basel.

\section{References}

1. Mehnert, H.: Die Verwertung von Xylit bei parenteraler Ernährung. In: Parenterale Ernährung, p. $28 \mathrm{ff}$., eds. Lang, K., Frey, R., and Halmagyi, M. BerlinHeidelberg-Now York: Springer 1966.

2. Mellinghoff, C.H.: Xylit, über die Verwertbarkeit als Ersatzzucker bei Diabetikern. Klin. Wschr. 39, 447 (1961).

3. Kieckebusch, W., Gziem, W., Lang, K.: Die Verwertbarkeit von $X_{y}$ lit als Nahrungskohlehydrat und seine Verträglichkeit. Klin. Wschr. 39, 447-448 (1961).

4. Miller, M., Craig, J.W., Drucker, W.R., Woodward, H.J.: The metabolism of fructose in man. Yale J. Biol. Med. 29, 335-360 (1956).

5. Smith, L. H., Ettinger, R.H., Seligson, D.: A comparison of the metabolism of fructose and glucose in hepatic diseases and diabetes mellitus, J. clin. Invest. 32, 273-282 (1953).

6. Adcock, L.H., Gray, C.H.: The metabolism of sorbitol in the human subject. Biochem. J. 65, 554-560 (1957).

7. Steinke, J., Wood, F.C., Domenge, L., Marble, A., Renold, A.E.: Evaluation of sorbitol in the diet of children at camp. Diabetes 10, 218-227 (1961).

8. Bässler, K. H., Prellwitz, W.: Insulin und der Verteilungsraum von Xylit bei eviscerierten Ratten. Klin. Wschr. 42, 94-95 (1964).

9. von Holt, C., Schmidt, H., Feldmann, H.: Der Anteil der Glucoseoxydation an der Kohlendioxydproduktion der Ratte. Biochem. Z. 334, 545-559 (1961).

10. Junod, A., Lambert, A.E., Stauffacher, W., Renold, A. E.: Diabetogenic action of Streptozotocin: Relationship of dose to metabolic response. J. clin. Invest. 48, 2129-2139 (1969).

11. Folch, J., Lees, M., Sloane, Stanley, G.H.: A simple method for the isolation and purification of total lipids from animal tissues. J. biol. Chem. 226, 497-509 (1957).

12. Touster, O.: Essential pentosuria and the glucuronate-xylulose pathway. Fed. Proc. 19, 977-983 (1960).

13. Landau, B.R., Bartsch, G.E., Williams, H.R.: Estimation of the glucuronic acid pathway contribution to glucose metabolism in adipose tissue and the effect of growth hormone. J. biol. Chem. 241, 750-760 (1966).

14. Hiatt, H.H.: Pentosuria, in: The metabolic basis of inherited disease, 2 nd ed., p. $109 \mathrm{ff}$. New York: Mc Graw Hill Book Comp. 1966.

15. Hollmann, S.: Nicht glykolytische Stoffwechselwege der Glucose. Stuttgart: Thieme-Verlag 1961.

16. Heinz, F., Lamprecht, W., Kirsch, J.: Enzymes of fructose metabolism in human liver. J. clin. Invest 47, $1826-1832$ (1968).

17. Schmidt, B., Fingerhut, M., Lang, K.: Über den Stoffwechsel von radioaktiv markiertem Xylit bei der Ratte. Klin. Wschr. 42, 1073-1077 (1964).

18. Bässler, K.H., Prellwitz, W., Lang, K., Unbehaun, V.: Xylitstoffwechsel beim Menschen, zur Frage der Eignung von Xylit als Ersatzzucker beim Diabetiker. Klin. Wschr. 40, $791-793$ (1962).

19. Yamagata, S., Goto, Y., Ohneda, A., Anzai, M., Kawashima, S., Chiba, M.: Clinical effects of xylitol on carbohydrate and lipid metabolism in diabetes. Lancet 1965 II, 918-921. 
20. Bässler, K.H., Toussaint, W., Stein, G.: Xylitverwertung bei Frühgeborenen, Säuglingen, Kindern und Erwachsenen. Klin. Wschr. 44, 212-215 (1966).

21. Mehnert, H., Summa, J.D., Förster, H. : Untersuchungen zum Xylit-Stoffwechsel bei gesunden, leberkranken und diabetischen Personen. Klin. Wschr, 42, $382-387(1964)$.

22. Spitz, I.M., Rubenstein, K.H., Bässler, K.H. : Metabolism of xylitol in healthy subjects and patients with renal disease. Metabolism 19, 24-34 (1970).

23. Kuzuya, T., Kanazawa, Y., Kosaka, K. : Plasma insulin response to intravenously administered xylitol in dogs. Metabolism 15, 1149-1152 (1966).

24. - - - Stimulation of insulin secretion by xylitol in dogs. Endocrinology 84, 200-207 (1969).

25. Schultis, K., Geser, C.A.: Observations on the anticatabolic effect of xylitol in the posttraumatic phase. Pentoses and Pentitols, p. 379. Berlin-Heidelberg-New York: Springer 1969.

26. Griem, W., Lang, K.: Pathologisch-histologische Untersuchungen an Rattenorganen nach parenteraler Xylitverabreichung. Klin. Wschr. 40,801-802 (1962)

27. Donahoe, J.F.: Biochemical abnormalities with xylitol. New Engl. J. Med. 282, 690-691 (1970).

28. Levine, R., Huddleston, B.: The comparative action of insulin on the disposal of intravenous fructose and glucose. Fed. Proc. 6, 151-152 (1947).

29. Leuthardt, F., Testa, E.: Die Phosphorylierung der Fruktose in der Leber. Helv. chim. Acta 34, $931-$ $938(1951)$.

30. McIntyre, N., Turner, D.S., Holdsworth, C.D.: The role of the portal circulation in glucose and fructose tolorance. Diabetologia 6, 593-596 (1970).

31. Froesch, F.R., Ginsberg, J.L.: Fructose metabolism of adipose tissue. J. biol. Chem. 237, 3317-3324(1962),

32. Ginsberg, J.L.: Fruktosestoffwechsel des Fettgewebes. II. Abbau der Fruktose im epididymalen Fettgewebe der Ratte. Z. ges. exp. Med. 139, 101-111 (1965).

33. Cori, C.F.: The fate of sugar in the animal body. I. The rate of absorption of hexoses and pentoses from the intestinal tract. J. biol. Chem. 66, $691-715$ (1925).

34. Darlington, W., Quastel, J.H.: Absorption of sugars from the isolated surviving intestine, Arch. Biochem. 43, 194-207 (1953).

35. Ginsburg, V., Hers, H.G.: On the conversion of fruetose to glucose by guinea pig intestine. Biochim. biophys. Acta 38, 427-434 (1960).

36. Cook, G.C.: Absorption products of d-fructose in man. Clin. Sci. 37, 675-687 (1969).

37. Froesch, E.R., Zapf, J., Keller, U., Oelz, O.: Comparative study of the metabolism of fructose, sorbitol and $x y$ litol- $\mathrm{U}^{14} \mathrm{C}$ in the normal and in the streptozotocin-diabetic rat. Europ. J. clin. Invest, in press.

38. Hers, H.G.: L'aldose reductase: Le mécanisme de la formation du fructose séminal et du fructose foetal. Biochim. biophys. Acta 37, 120-126 (1960).

39. Clements, R.S., Jr., Prockop, L.D., Winegrad, A.I.: Acute cerebral edema during treatment of hyperglycemia, an experimental model. Lancet $1968 \mathrm{II}, 384-$ 386.
40. Gabbay, K.H., O'Sullivan, J,B.: The sorbitol pathway, enzyme localization and content in normal and diabetic nerve and eord. Diabetes 17, 239-243 (1968).

41. Clements, R.S., Jr., Morrison, A. D., Winegrad, A.I.: Polyol pathway in aorta: Regulation by hormones. Science 166, $1007-1008$ (1969).

42. Lerman, S.: Metabolic pathways in experimental sugar and radiation cataract. Physiol. Rev. 45, 98-122 (1965).

43. Blakely, R.L.: Metabolism and antiketogenic effects of sorbitol. Sorbitoldehydrogenase. Biochem. J. 49, $257-271(1951)$.

44. Friedmann, B., Goodman, E.H.Jr., Weinhouse, S.: Liver glycogen synthesis in intact alloxan diabetic rats. J. biol. Chem. 238, 2899-2905 (1963).

45. Salas, M., Vinuela, E., Sols, A.: Insulin dependent synthesis of liver glucokinase in the rat. J. biol. Chem. $238,3535-3538(1963)$.

46. Froesch, E.R.: Fructose metabolism of adipose tissue from normal and diabetie rats. In: A.E. Renold, G.F. Cahill Jr., Eds., Handbook of Physiology, Section V, "Adipose Tissue", American Physiol. Society, Washington DC, 1965, p. 281-293.

47. Baker, N., Shipley, R.A., Clark, R.E., Incefy, G.E.: ${ }^{14} \mathrm{C}$-studies in carbohydrate metabolism. III. Glucose pool size and rate of turnover in the normal rat. Amer. J. Physiol. 196, 245-252 (1959).

48. Wick, A.N., Morita, T.N., Barnet, H.N.: Sorbitol metabolism in alloxan diabetic animals as compared with fructose and glucose. Food Res. 20, 66-70 (1955).

49. Hers, H.G.: The conversion of fructose-1.14C and sorbitol-1.14 $\mathrm{C}$ to liver and muscle glycogen in the rat. J. biol. Chem. 214, 373-381 (1955).

50. Muntz, J.A., Vanko, M.: The metabolism of intraportally injected fructose in rat liver in vivo. J. biol. Chem, 237, 3582-3587 (1962).

51. Felber, J.P., Renold, A.E., Zahnd, G.R.: The compared metabolism of glucose, fructose, galactose and sorbitol in normal subjects and diseased states. Mod. Probl. Pediat. 4, 467-489 (1959).

52. Baker, N., Huebotter, R.: Glucose metabolism in mice. Amer. J. Physiol. 207, 1155-1160 (1964).

53. Fredrickson, D.S., Gordon, R.S., Jr.: Fatty aeid transport. Physiol. Rev. 38, 585-630 (1958).

54. Balasse, E. O.: Inhibition of free fatty acid oxidation by acetoacetate in normal dogs. Europ. J. clin. Invest. $1,155-160(1970)$.

55. Depocas, F.: Glucose oxidation in the alloxan-diabetic rat. Amer. J. Physiol. 206, 119-123 (1964).

Prof. Dr. E.R. Froesch

Metabolie Unit

Dept. of Medicine University of Zürich

CH.8006 Zürich

Rämistr. 100

Switzerland 